\title{
Wielkotygodniowe inspiracje w hymnografii Zaśnięcia Bogurodzicy
}

\author{
ks. hieromnich Pantelejmon Karczewski \\ Chrześcijańska Akademia Teologiczna, Wydział Teologiczny, Polska \\ ORCID: 0000-0003-0829-1781 \\ pantelejmon.karczewski@gmail.com
}

rev. P. Karczewski, Inspirations of the Holy Week in the hymnography of the Dormition of the Mother of God, Elpis, 23 2021: 19-28.

\begin{abstract}
Dormition of the Mother of God is one of the most solemnly celebrated feasts in the Orthodox liturgical year. It has a rich hymnography, including an additional rite of the Funeral of the Mother of God. The texts of the feast are largely inspired by the hymnography of the Holy Week, and especially Holy Saturday. This paper presents, on the example of the feast of the Dormition, a general phenomenon of intertextuality in hymnography. Mutual interpenetration of hymns appears in the context of many feasts and many saints.
\end{abstract}

\begin{abstract}
Streszczenie: Zaśnięcie Bogurodzicy to jedno z najbardziej uroczyście obchodzonych świąt w prawosławnym roku liturgicznym. Ma bogatą hymnografię, w tym dodatkowy obrzęd Pogrzebu Bogurodzicy. Teksty święta są w dużej mierze inspirowane hymnografią Wielkiego Tygodnia, a zwłaszcza Wielkiej Soboty. Niniejszy artykuł prezentuje na przykładzie święta Zaśnięcia Bogurodzicy ogólne zjawisko intertekstualności w hymnografii. Wzajemne przenikanie się tekstologiczne hymnów pojawia się bowiem w kontekście wielu świąt i wielu świętych.
\end{abstract}

Keywords: Dormition, Mother of God, Holy Week, hymnography, funeral

Słowa kluczowe: Zaśnięcie, Bogurodzica, Wielki Tydzień, hymnografia, pogrzeb

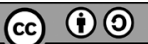

Zaśnięcie Bogurodzicy należące do dwunastu największych świąt $\mathrm{w}$ prawosławnym kalendarzu liturgicznym jest najbardziej uroczyście obchodzonym świętem maryjnym. Cechuje je bogata hymnografia. Wyjątkowość tego święta podkreślana jest przez użycie najuroczystszych tonalnych linii melodycznych, a także zaawansowaną poetyckość tekstów liturgicznych. Ze świętem Zaśnięcia związany jest późniejszy niż samo ustanowienie uroczystości obrzęd pogrzebu Bogurodzicy inspirowany hymnografią Wielkiego Piątku i Wielkiej Soboty, a często wręcz parafrazujący niektóre teksty. Inspiracje wielkotygodniowe cechują teksty nie tylko pogrzebu, ale i całą świąteczną hymnografię.

\section{Zaśnięcie Bogurodzicy w tradycji liturgicznej}

Zaśnięcie Bogurodzicy to jedno z dwóch świąt z grupy dwunastu (obok Podwyższenia Krzyża Pańskiego), które dotyczy wydarzenia, jakie miało miejsce już po Pięćdziesiątnicy. To jedno z czterech świąt $\mathrm{w}$ roku (obok Paschy, Narodzenia Chrystusa i wspomnienia apostołów Piotra i Pawła) poprzedzonych wielodniowym postem.

Opisu Zaśnięcia nie dostarcza Ewangelia, lecz inne teksty narracyjne. Po Wniebowstąpieniu Chrystusa, Bogurodzica, zgodnie z wypowiedzianymi przez Zbawiciela wiszącego na krzyżu słowami, pozostała pod opieką apostoła Jana. Nieustannie przebywała w modlitwie. Pod koniec życia mieszkającej w Jerozolimie Marii objawił się archanioł Gabriel, który zwiastował Jej zbliżające się odejście. W dniu Jej zaśnięcia apostołowie $-\mathrm{z}$ wyjątkiem Tomasza - zostali w cudowny sposób przeniesieni na obłokach do Jerozolimy. Uczestniczyli w Jej wyjątkowym pogrzebie. Zgodnie z przekazem, sam Chrystus przyjął duszę Swojej Czcigodnej Matki, co zilustrowane zostało w ikonografii święta Zaśnięcia (Quenot, 2001, s. 199). Ciało Bogurodzicy pochowano, zgodnie z Jej wolą, w ogrodzie Getsemani w pobliżu grobów Jej rodziców i św. Józefa Oblubieńca. Absencja Tomasza znajduje swoje cudowne uzasadnienie trzeciego dnia po odejściu Matki Bożej. Przybył on spóźniony i pragnął ujrzeć po raz ostatni Bogurodzicę. Oczom wszystkich ukazał się jednak pusty grób bez ciała Matki Bożej. Tomasz, będąc po Zmartwychwstaniu Chrystusa wątpiącym apostołem, po Zaśnięciu Bogurodzicy stał się tym, dzięki któremu wszyscy przekonali się o Jej przejściu na niebiosa wraz $\mathrm{z}$ ciałem.

\section{Rys historyczny}

O świętowaniu Zaśnięcia Bogurodzicy czytamy u pisarzy kościelnych z przełomu IV i V wieku, jak chociażby błog. Hieronima ze Strydonu i błog. Augustyna z Hippony (Charkiewicz, 2013, s. 158). W IV wieku święto to było obchodzone w Konstantynopolu. W 595 r. cesarz Maurycy, który odniósł zwycięstwo nad Persami w dniu 15 sierp- 
nia, ustanowił święto Zaśnięcia właśnie na ten dzień i podniósł jego rangę do ogólnokościelnej (Charkiewicz, 2013, s. 161). Przez lata istniały jednak rozbieżności co do daty święta. W jednych tradycjach obchodzono je w styczniu, w innych w sierpniu. W tradycji rzymskiej Zaśnięcie rozdzielone było na dwie uroczystości: 18 stycznia celebrowano Zaśnięcie (depositio), a 14 sierpnia Wniebowzięcie (assumptio). Praktyka wspólnego obchodzenia święta na Wschodzie i Zachodzie w dniu 15 sierpnia pochodzi z VIII -IX w. (Charkiewicz, 2013, s. 161).

\section{Święto Zaśnięcia w kalendarzu liturgicznym}

Święto poprzedza czternastodniowy post, który swojej srogości ustępuje jedynie Wielkiemu Postowi. Czyni to z Zaśnięcia swoistą teomitoryczną Paschę. Spośród dwunastu wielkich świąt jeszcze tylko dwa poprzedzone są postem ewidentnie z nimi związanym - Narodzenie Chrystusa (czterdziestodniowy post) i Epifania (jednodniowy post). Rygor żywieniowy w poście przed Zaśnięciem zakłada rezygnację z mięsa, nabiału i ryb (ryby zezwala się spożywać jedynie w święto Przemienienia Pańskiego - 6 sierpnia), a w dni powszednie nieświąteczne także $\mathrm{z}$ oleju. Reguły liturgiczne przewidują także możliwość sprawowania wielkopostnego nabożeństwa ze śpiewem „Alleluja” zamiast „Bogiem jest Pan” na jutrzni i recytacją modlitwy św. Efrema Syryjczyka z pokłonami (w obecnej praktyce słowiańskiej bardzo rzadkie jest sprawowanie wielkopostnego nabożeństwa poza Wielkim Postem). Większość postnych dni to jednak wspomnienia ważniejszych świętych bądź okres poświąteczny Przemienienia, stąd też w praktyce sprawowanie nabożeństwa o charakterze wielkopostnym możliwe jest tylko dwukrotnie (Skaballanovich, 2004, s. 114).

Zaśnięcie ma jeden dzień przedświąteczny (14 sierpnia), który swoją hymnografią przygotowuje i zachęca do celebrowania wydarzenia. Niektóre teksty liturgiczne pochodzą już bezpośrednio z nabożeństwa samego święta. Okres poświąteczny rozpoczynający się 16 sierpnia trwa aż osiem dni. To największa możliwa liczba świątecznej oktawy dla świąt $\mathrm{z}$ grupy dwunastu. Osiem dni trwa również poświęcie Epifanii (Narodzenie Chrystusa ma o wiele krótszy okres poświąteczny [od 26 do 31 grudnia] z uwagi na święto Obrzezania Pańskiego, które obchodzone jest właśnie ósmego dnia.). Warto dodać, że pozostałe święta maryjne mają okres poświąteczny rzędu maksymalnie czterech dni.

\section{Hymnografia święta}

Teksty liturgiczne na święto Zwiastowania pochodzą z V-VIII wieku. Już w V w. stichery napisał patriarcha Konstantynopola Anatol. Kanony z jutrzni należące do św. Kosmy z Majumy i św. Jana z Damaszku pochodzą z VIII w. (Pljukhanova, 2016, s. 58-59).

\section{Warstwa muzyczna}

Analiza strony muzycznej hymnografii święta prowadzi do wniosku, że to najbardziej uroczyste ze wszystkich świąt maryjnych, a także jedno z najbardziej uroczystych ze wszystkich dwunastu największych świąt. Świadczy o tym choćby często obecny pierwszy ton, w którego melodii śpiewany jest np. kanon na jutrzni. Taka muzyczna podniosłość hymnów cechuje jeszcze dwa święta - Paschę i Boże Narodzenie. Cytując za Skaballanovichem, „takiej radości nie słychać na żadnym innym nabożeństwie jakiegokolwiek święta z grupy dwunastu - ani chrystusowego, ani maryjnego" (Skaballanovich, 2004, s. 107).

Ważnym ewenementem celebracji Zaśnięcia $\mathrm{w}$ tradycji wschodniosłowiańskiej jest sposób śpiewu stichery kończącej cykl na „Panie, wołam” na wieczerni („,Богоначальным мановением”). W tradycji Kijowsko -Peczerskiej Ławry poszczególne wersy tejże stichery śpiewane są na wszystkie kolejne tony muzyczne. Jedynie pierwsza i ostatnia strofa hymnu wykonywane są według melodii pierwszego tonu.

\section{Warstwa tekstologiczna}

Hymnografia święta Zaśnięcia należy do kilku autorów, m.in. św. Anatola z Konstantynopola, św. Jana z Damaszku, św. Kosmy z Majumy. Głównymi tematami tekstów są: 1) parafraza opisu Zaśnięcia; 2) misterium Wcielenia Chrystusa; 4) orędownictwo Matki Bożej nad światem. Hymnografia święta inspiruje się hymnografią wielkotygodniową i bożonarodzeniową.

Już pierwsza stichera wychwala i zaśnięcie Bogurodzicy i samą Matkę Bożą. Nastrój hymnu jest bardzo triumfalny, a sichera stanowi jeden z najbardziej znamienitych utworów święta - „O, przesławny cud! Źródło życia spoczęło w grobie i grób staje się drabiną do nieba. Wesel się, Getsemani, święty domu Bogurodzicy" (Miesiaca sierpnia 15 dnia, s. 1). Temat poetyckiego opisu pogrzebu Bogurodzicy kontynuują kolejne stichery $\mathrm{z}$ tego cyklu, a także stichery na litii mówiące o przybyciu apostołów - „Należało, aby świadkowie i słudzy Słowa widzieli także Zaśnięcie Jego Matki, Jej ostatnią tajemnicę na ziemi, aby nie tylko zobaczyli wniebowstąpienie Zbawcy, ale zaświadczyli też o odejściu Jego Rodzicielki" (Miesiqca sierpnia 15 dnia, s. 2).

Tematyka większości sticher jest radosna i triumfalna - wyraża radość z faktu Zaśnięcia i jednocześnie wstąpienia Bogurodzicy do niebios z duszą i ciałem. Śpiewana po lekturze Ewangelii po psalmie 50. stichera ma jednak nieco inny charakter. Związana jest ona z psalmem o charakterze pokutnym, a zatem i w swojej treści wyraża smutek apostoła Piotra - „Patrząc z lękiem na ciało Twoje, Piotr wołał, płacząc: 'O, Dziewico! Widzę Ciebie leżącą martwą, życie wszystkich, i dziwię się, gdyż w Ciebie wcieliła się słodycz przyszłego życia" (Miesiąca sierpnia 15 dnia, s. 5).

Święty Jan z Damaszku w swoim kanonie z jutrzni podkreśla, że fizyczne odejście Matki Bożej jest faktem natu- 
ralnym, zwłaszcza w kontekście śmierci Jej Syna - ,Jeżeli Jej niedościgniony owoc, przez który stały się niebiosa, przyjął dobrowolnie pogrzeb i jako martwy spoczął w grobie, jakże uniknie pogrzebu Ta, która w dziewictwie porodziła?” (Miesiaca sierpnia 15 dnia, s. 7). Święty poeta dodaje w innym miejscu, że również logiczny pozostaje fakt, że Ciało Matki Bożej nie uległo zepsuciu - ,w zrodzeniu zachował bowiem Ciebie Dziewicą i w grobie ciało zachował Twe nienaruszone" (Miesiaca sierpnia 15 dnia, s. 7). Nieuleganie Ciała Bogurodzicy naturalnemu zepsuciu hymnograf zestawił z nieutraceniem przez Matkę Bożą czystości dziewictwa.

W uroczystym odejściu Matki Bożej do wieczności i jej pogrzebie uczestniczy świat anielski, o czym mówią liczne hymny, jak chociażby trzecia stichera z wieczerni święta, w której wymieniane są poszczególne chóry anielskie wychwalające wydarzenie - „Sławią Twoje Zaśnięcie Władze i Trony, Księstwa i Panowania, Moce i Cherubini, i straszni Serafini, radują się zrodzeni z ziemi, upiększeni Boską Twoją chwałą. Przypadają królowie z Archaniołami i Aniołami" (Miesiąca sierpnia 15 dnia, s. 1).

Innym motywem hymnografii święta jest misterium Wcielenia Chrystusa. To temat jednej ze sticher na litii „Najczystsza Niewiasta i Matka Jezusa Chrystusa, wybrana przez Boga, stała się przybytkiem, w którym zjednoczone zostały Boska i ludzka natura” (Miesiąca sierpnia 15 dnia, s. 3). Bogurodzica określana jest także jako „Arka Boga" (Miesiaca sierpnia 15 dnia, s. 3).

O wiecznym dziewictwie Bogurodzicy nazywanej Zawsze Dziewicą (gr. Aeiparthenos, cs. Prisnodiewa) wspomina chociażby główny świąteczny hymn - troparion - i to już w pierwszych słowach - „W narodzeniu dziewictwo zachowałaś” (Miesiąca sierpnia 15 dnia, s. 2). O dziewiczym zrodzeniu mówi też katyzma poetycka z jutrzni, tym razem porównując dziewicze poczęcie do faktu fizycznego nienaruszenia ciała Matki Bożej po zaśnięciu - „W zrodzeniu Twym poczęcie dziewicze, w zaśnięciu Twym ciało niezniszczalne, cud z cudem ściśle się łączy, Bogurodzico" (Miesiaca sierpnia 15 dnia, s. 4). W słowach kanonu z jutrzni św. Kosma z Majumy wzywa: „Zwycięstwo odniosłaś nad naturą, Dziewico, rodząc Boga" (Miesiąca sierpnia 15 dnia, s. 5).

Trzecim ważnym motywem tekstów święta jest myśl o nieustannym orędownictwie Matki Bożej za wszystkich wiernych. Hymny podkreślają, że fizyczne odejście Bogurodzicy ze świata nijak nie umniejsza Jej wstawiennictwa za cały świat. Troparion święta rozpoczyna się dwoma paralelnymi zdaniami - „W narodzeniu dziewictwo zachowałaś, w zaśnięciu świata nie porzuciłaś, Bogurodzico" (Miesiaca sierpnia 15 dnia, s. 4). Tak jak podczas Narodzin Syna Bożego Bogurodzica pozostała dziewicą, tak i po Swoim zaśnięciu pozostała Ona orędowniczką za cały świat. Kontakion dodaje, że śmierć nie jest w stanie zatrzymać Matki Bożej w jej modlitwach za świat - „Nieustającej w modlitwach Bogurodzicy i w orędownictwie stałej nadziei ani grób ani śmierć nie zatrzymały" (Th IE, tou autou mhnos, tłum. własne).

Jednym z ważniejszych hymnów opiewających orędownictwo Matki Bożej jest hypakoe recytowany po trze- ciej pieśni kanonu jutrzni. Czytamy w nim: „Błogosławieni jesteśmy i my, Twoje mając orędownictwo, bowiem dzień i noc modlisz się za nami i podstawy królestwa umacniają się przez Twoje modlitwy" (Miesiaca sierpnia 15 dnia, s. 6). Warto odnotować fakt, że utwór ten śpiewany jest podczas obrzędu Panagii sprawowanego po świątecznych i niedzielnych obiadach we wspólnotach monasterskich.

O orędownictwie Matki Bożej mówi ponadto ostatnia stichera na „Panie, wołam” z wieczerni - „Najczystsza Bogurodzico, która zawsze przebywasz z Królem Dawcą Życia, Twoim Synem, módl się, aby zachował i wybawił od wszelkich przeciwności nowy Twój lud. Twoje bowiem orędownictwo mamy na wieki objawione w błogosławionej Światłości” (Miesiąca sierpnia 15 dnia, s. 1). Podmiot liryczny w innym hymnie wyraża myśl, że chrześcijanie pokładają w Bogurodzicy wielką nadzieję - ,Ty, jako Matka Stwórcy wszystkich, Chrystusa Boga, módl się do Niego nieustannie za nami, bowiem w Tobie złożyliśmy naszą nadzieję" (Miesiąca sierpnia 15 dnia, s. 3).

\section{Motywy i sformulowania z hymnografii Wielkiej Soboty}

Wzajemne podobieństwa tekstów liturgicznych różnych świąt czy świętych zawierają się w sferze treściowej i sferze językowej. Wśród pierwszej kategorii można mówić o logicznych podobieństwach, jak np. podobne sformułowania wobec świętych z tej samej kategorii czy np. wychwalanie Dziewictwa Bogurodzicy w hymnografii niemal wszystkich, tak różnorodnych świąt maryjnych. Są też podobieństwa polegające na zestawieniu wspólnych cech wydarzeń lub ich skontrastowanie, jak np. wspólna dla hymnografii i ikonografii analogia między Bogurodzicą trzymającą na rękach Chrystusa a Chrystusem trzymającym na rękach duszę Bogurodzicy po Jej Zaśnięciu. Drugą sferą podobieństw między hymnami jest sfera językowa. Hymnografowie parafrazowali różne utwory, przekształcając je na potrzeby innego wydarzenia, czego przykładem może być stichera godzin kanonicznych Wielkiego Piątku, XV antyfona jutrzni pasyjnej „Dzisiaj wisi na krzyżu”, którą na potrzeby wigilii Narodzenia Chrystusa przekształcono na wersję bożonarodzeniową, zachowując strukturę i podobne sformułowania. Egzemplifikacją wzajemnego przenikania się utworów liturgicznych może być hymnografia Zaśnięcia Bogurodzicy, odwołująca się wielokrotnie do hymnografii Wielkiej Soboty.

$\mathrm{Na}$ jutrzni Zaśnięcia śpiewane są dwa kanony autorstwa dwóch wybitnych hymnografów, przyrodnich braci - św. Jana z Damaszku i św. Kosmy z Majumy. Pierwszy $\mathrm{z}$ nich śpiewany jest $\mathrm{w}$ możliwie najbardziej uroczystym tonie - pierwszym. Drugi z nich - w tonie czwartym. Kanonu, co prawda nie można w żaden sposób uznać za kalkę kanonu Wielkiej Soboty - ani w kwestii linii melodycznej ani warstwy tekstowej - znaleźć w nim można jednak wiele wspólnych elementów.

Wielkosobotni kanon „,Wotnoju morskoju” jest kompilacją tekstów trzech pisarzy - św. Kosmy, Marka z Otran- 
to i św. Kasji. Autorstwo troparionów pieśni od szóstej do dziewiątej (czwórpieśniec) przypisuje się św. Kosmie. Do troparionów dodano hirmosy autorstwa mniszki Kasji. Kanon rozwinięto następnie do formy pełnego kanonu uzupełniając go o pieśni od pierwszej do piątej (z tradycyjnym pominięciem pieśni drugiej), do których tropariony napisał Marek z Otranto (Karabinov, 1910, s. 185). Kanon wyraża myśl, że Chrystus przyszedł na świat, by zbawić ludzkość, która upadła z winy Adama. Poeta opisuje też wpływ męki i śmierci Chrystusa na jego obie natury. Ważnym tematem kanonu jest odnowienie przez Chrystusa ludzkiej natury ponowne stworzenie człowieka. Kanon kończy się wielką nadzieją Zmartwychwstania. Hirmos dziewiątej pieśni, który powtórzony będzie na wielkosobotniej Liturgii to słowa Chrystusa do Bogurodzicy: „Nie płacz nade mną, Matko, widząc w grobie Syna" (Wielki Tydzień, 2003, s. 137).

Pierwszy troparion kanonu św. Jana na dzień Zaśnięcia adresowany jest do „młodych dziewic” - „Zakrzyknijcie

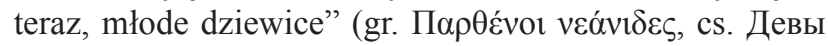
отроковицы). Przypomina to pierwszy hirmos Wielkiej Soboty, gdzie padają słowa „ale my, jak niegdyś dziewi-

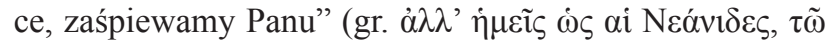
Kvpí $\omega$ ö $\sigma \omega \mu \varepsilon v)$. To nawiązanie do opisu przejścia Izraelitów przez Morze Czerwone, któremu poświęcona jest zawsze pierwsza pieśń kanonu. W opisie czytamy: „Miriam prorokini, siostra Aarona, wzięła bębenek do ręki, a wszystkie kobiety szły za nią w pląsach i uderzały w bębenki. A Miriam przyśpiewywała im: «Śpiewajmy pieśń chwały na cześć Pana, bo swą potęgę okazał, gdy konie i jeźdźców ich pogrążył w morzu»" (Wyj 15,20). W kontekście święta Zaśnięcia to także reminiscencja Wprowadzenia Bogurodzicy do świątyni, w którym to wydarzeniu uczestniczyło także wiele dziewczynek odprowadzających przyszłą Matkę Bożą do świątyni.

Podmiot liryczny wzywa owe niewiasty do zaśpiewania pieśni pogrzebowej - „Zakrzyknijcie teraz (...) pieśń odejścia” (Miesiąca sierpnia 15 dnia, s. 6). Owa „pieśń

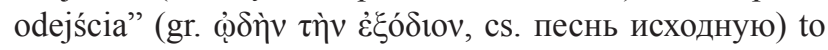
sformułowanie, którym hymnograf rozpoczyna pierwszy troparion kanonu Wielkiej Soboty - „Panie, Boże mój, pieśń odejścia i nadgrobny śpiew zaśpiewam Tobie" (Ako-

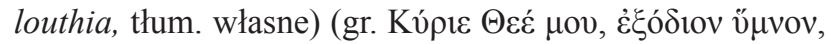

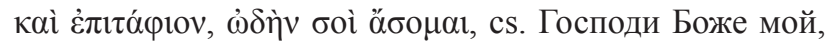
исходное пение, и надгробную Тебе песнь воспою).

Pierwsza pieśn dostarcza jeszcze jednej myśli związanej z kanonem Wielkiej Soboty. Dostrzeżemy ją, cofnąwszy się do pierwszej ody kanonu św. Kosmy - „umarłszy, powstajesz z Synem do życia wiecznego" (Th IE'tou

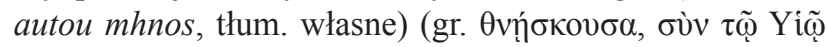

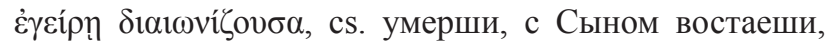
вечнующи). Koresponduje to z dziewiątą pieśnią kanonu Błogosławionej Soboty, w której Chrystus zapowiada swoje zmartwychwstanie, a wespół z tym wydarzeniem także wychwalenie Swojej Przeczystej Matki i wszystkich tych, którzy Ją czczą - ,powstanę bowiem i wysławię się, i jako Bóg wyniosę w chwale tych, którzy nieustannie w wierze i miłości Ciebie wywyższają" (Wielki Tydzień, 2003, s. 137).
Drugi troparion trzeciej pieśni kanonu św. Kosmy odnosi się do cudu, jaki miał miejsce podczas pogrzebu Bogurodzicy. Przechodzący obok żydowski arcykapłan Atoniusz, chcąc zatrzymać procesję, powziął próbę zbezczeszczenia ciała Bogurodzicy. Jego ręce zostały jednak niewidzialną mocą odcięte (Na wielu freskach i ikonach tradycji bałkańskiej przedstawiony jest archanioł Gabriel odcinający ręce Atoniuszowi). Później kapłan nawrócił się i otrzymał uzdrowienie. W kanonie czytamy - „Dosięga ręce zuchwalcy Boży wyrok odrąbania, bowiem Pan zachowuje cześć dla duchowej Arki i sławy Boga, w której Słowo stało się ciałem" (Miesiaca sierpnia 15 dnia, s. 6). Początkowe sformułowanie odwołuje się do faktu wyciągnięcia rąk przez żydowskiego kapłana w złym celu. Koresponduje to z troparionem kanonu Wielkiej Soboty umieszczonym $\mathrm{w}$ identycznym pod względem struktury miejscu (drugi troparion trzeciej pieśni) - „Zbawco, rozpostarłeś ręce...”. W tym jednak przypadku sformułowanie to odnosi się do ukrzyżowania Chrystusa - rozpostarcia Jego rąk podczas śmierci na krzyżu, dzięki któremu nastąpiło zwycięstwo życia nad śmiercią.

W pierwszym troparionie ósmej pieśni (kanonu św. Kosmy) słyszymy narrację: „Mnóstwo teologów szło na Syjonie za świętą Arką, tak wołając: 'Gdzie idziesz teraz, Arko Boga żywego?"” (Miesiaca sierpnia 15 dnia, s. 9)

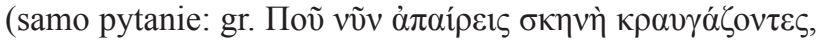

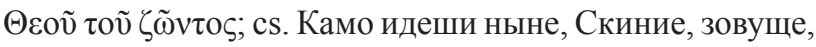
Бога живаго?). Pytanie skierowane do Matki Bożej przypomina pytanie, jakie zadaje Matka Boża Chrystusowi w kontakionie Wielkiego Piątku autorstwa św. Romana Melodosa - „Gdzie podążasz, Dziecię?” (Wielki Tydzień,

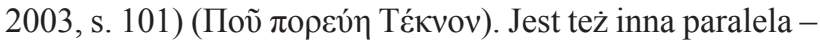
w tym samym miejscu kanonu Wielkiej Soboty (pierwszy troparion ósmej pieśni) czytamy: „Rozpada się przeczysta świątynia, ale podnosi upadły przybytek" (Wielki Tydzień,

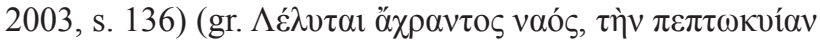

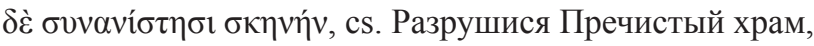
падшую же совозставляет скинию). Termin „przybytek” bądź ,arka”, którego desygnat podnosi się wraz ze śmiercią Chrystusa na krzyżu, odwołuje się do ludzkiej natury (Por. 2 Kor 5,1). W przypadku tekstologii Zaśnięcia słowo „arka” określa Bogurodzicę, która przyjęła do Swojego łona wcielonego Syna Bożego. Termin „arka” pojawia się dość często w hymnografii Wprowadzenia Bogurodzicy do świątyni.

W tej samej ósmej pieśni czytamy o grobie Matki Bożej - „W grobie zamieszkawszy uczyniła go rajem” (Miesiąca sierpnia 15 dnia, s. 9). Tekst wiąże się z dwoma innymi wielkosobotnimi hymnami. W siódmej pieśni kanonu św. Kosma opowiada o grobie Zbawiciela - „Bogaty grób, przyjął bowiem w siebie Stwórcę jako śpiącego, życia Boskiego skarbnicą okazał się" (Великий Сборник, s. 549). O grobie opowiadają także inne niektóre teksty, ale głównym z nich - świetnie korespondującym z cytowanym - jest troparion śpiewany podczas paschalnych godzin kanonicznych oraz po położeniu Darów na ołtarzu podczas śpiewu Cherubikonu na Świętej Liturgii - „Zaprawdę piękniejszy od raju i jaśniejszy od pałacu królew- 
skiego, okazał się dla nas, Chryste, Grób Twój życiodajny, Źródło naszego zmartwychwstania" (Wielki Tydzień, 2003, s. 166).

Ten sam troparion cechuje także rozpoczynające go wykrzyknienie „O, przewyższające rozum cuda Dziewi-

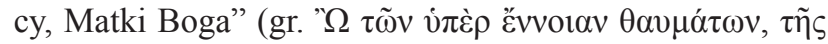

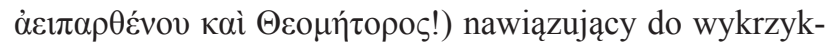
nienia z ósmej pieśni kanon Wielkiej Soboty - „O, niezwykłe cuda! O, łasko! O, niewypowiedziana cierpliwości!”

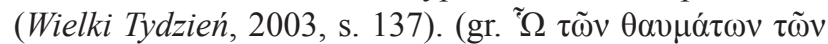

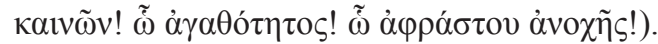

Inna paralela dostrzegalna $\mathrm{w}$ hymnografii związana jest z określeniem Chrystusa mianem „Życia”. W tenże sposób rozpoczynają się wielkosobotnie lamentacje "Chryste, Ty będąc Życiem, złożony zostałeś w grobie" (Wielki Tydzień, 2003, s. 106). Matka Boża, jako ta, która zrodziła Chrystusa, nazywana jest „źródłem życia” (gr. $\dot{\eta}$ $\pi \eta \gamma \eta \grave{\tau} \tau \tilde{\varsigma} \zeta \omega \tilde{\zeta} \varsigma)$, co widzimy choćby w pierwszej sticherze wieczerni - „Źródło życia spoczęło w grobie” (Miesiąca sierpnia 15 dnia, s. 1).

Pośród wielkopiątkowych i wielkosobotnich hymnów odnoszących się do cierpień Matki Bożej stojącej pod krzyżem, Ta zwraca się wielokrotnie do Chrystusa z użyciem czasownika „widzieć” - „Widzę teraz Ciebie, ukochane i umiłowane moje Dziecko, na krzyżu wiszące" (Wielki Tydzień, 2003, s. 97), „Widzę moje dziecko w mych ramionach...” (Wielki Tydzień, 2003, s. 98), „Gdy widzę Ciebie związanego i bez chwały..." (Wielki Tydzień, 2003, s. 99). Nie sposób nie zauważyć w tych słowach inspiracji dla wspomnianej już stichery śpiewanej po 50. psalmie na jutrzni: „Piotr wołał, płacząc: 'O, Dziewico! Widzę Ciebie leżącą martwą..." (Miesiąca sierpnia 15 dnia, s. 5).

\section{Obrzęd Pogrzebu Bogurodzicy}

Ważnym elementem liturgicznych obchodów święta Zaśnięcia Bogurodzicy jest obrzęd Jej pogrzebu. Tekst nabożeństwa, jak i sam zwyczaj, są dość późne (najwcześniej ok. XV wieku), dlatego obrzęd nie jest sprawowany powszechnie. Warto przyjrzeć się tekstom liturgicznym owego nabożeństwa, będącego wspaniałym dziełem hymnograficznym - adaptacją nabożeństwa Wielkiej Soboty do potrzeb tematycznych pogrzebu Najświętszej Dziewicy.

\section{Rys historyczny}

Obrzęd Pogrzebu Bogurodzicy (cs. Czin pohrebienija Preswiatoj Bohorodicy) pojawia się w greckich i słowiańskich rękopisach od XV-XVI wieku. Jego autorstwo przypisuje się wybitnym greckim hymnografom, w szczególności wielkiemu retorowi Emanuelowi. Nabożeństwo przypomina wielkosobotnią jutrznię - wiele tekstów liturgicznych powstało właśnie przez sparafrazowanie hymnów nabożeństwa pogrzebu Chrystusa. Jako że obrzęd nie jest opisany w typikonie, istnieją liczne rozbieżności m.in. co do daty jego odprawiania. W niektórych katedrach lub monasterach (warto zaznaczyć, iż dawniej nabożeństwo to celebrowano jedynie w katedrach biskupich) pogrzeb sprawuje się w przeddzień święta, w innych podczas całonocnego czuwania, w jeszcze innych dwa, trzy dni po święcie.

Jeżeli obrzęd pogrzebu odbywa się oddzielnie od świątecznego całonocnego czuwania, to ryt przewiduje sprawowanie jutrzni, a przed nią także wieczerni (ta jest w praktyce często pomijana). Na wieczerni śpiewane są wówczas trzy stichery święta, a następnie pięć sticher z obrzędu pogrzebu, zwanego „obrzędem jerozolimskim”.

\section{Stichery wieczerni}

Pierwsza z jerozolimskich sticher to „Dzisiejszy dzień" - adaptacja doksastikonu szóstego tonu z wielkosobotniej jutrzni śpiewanego po psalmach pochwalnych.

Oryginalny hymn Wielkiej Soboty w swojej strukturze rozpoczyna się stwierdzeniem, że omawiany dzień jest wypełnieniem starotestamentowego proroctwa (1), następnie pojawia się cytat (2) i jego omówienie w kontekście wydarzeń nowotestamentowych (3). Tekst kończy się pełną nadziei zapowiedzią życia wiecznego (4):

„1) Dzisiejszy dzień tajemniczo prefigurował Mojżesz, mówiąc:

2) 'I pobłogosławił Bóg siódmy dzień'.

3) Oto jest błogosławiona sobota, oto dzień odpocznienia, w którym spoczął od wszystkich swoich dzieł Jednorodzony Syn Boży, który z Opatrzności przyjął śmierć, i odpoczywa cieleśnie w sobotę.

4) Ale On powróci przez swoje zmartwychwstanie, da nam życie wieczne, albowiem jest jedynym dobrym i Przyjacielem człowieka" (Wielki Tydzień, 2003, s. 139).

Podobnie zbudowany jest wspomniany hymn ku czci Bogurodzicy. Opiera się on jednak na dwóch proroctwach, zaczerpniętych tym razem z Psalmów Dawida:

„1) Dzisiejszy dzień tajemniczo prefigurował wielki psalmista, mówiąc:

2) 'Powstań, Panie, w Twoim spoczynku, Ty i arka świętości Twojej’ (Ps 131,8)

2) I jeszcze mówił: 'Stanęła królowa po Twojej prawicy, ubrana w szaty przetykane złotem i przyozdobiona' (Ps 44,10)

3) Oto jest błogosławiona sobota, oto dzień Bożego odpocznienia, w którym spoczęła Matka Życia, oddana śmierci, odpoczywająca ciałem, odchodząca i wstępująca na niebo, mocą z Niej wcielonego Chrystusa Boga, i z Nim na wieki wieków wiecznie żyjąca

4) i dająca życie wieczne nam, z miłością czczącym Jej święte zaśnięcie" (Miesiaca sierpnia 15 dnia, s. 12).

Hymn używa podobnych sformułowań w pierwszej i trzeciej części - w trzeciej chociażby nawiązania do szabatu, które w przypadku tekstu maryjnego może być mniej zrozumiałe. Nie chodzi o dzień tygodnia, ale o szabat jako odpoczynek - „сия бо есть благословенная суббота, сей есть упокоения [Божественный] день”. W Wielką Sobotę Kościół głosi, że szabat jest błogosławionym 
dniem spoczynku, w którym aktualnie odpoczywa w grobie Chrystus. Celebrując pogrzeb Najczystszej Dziewicy Kościół wskazuje, że szabat jest już uświęconym przez Boga - błogosławionym dniem Bożego spoczynku (dodając słowo „Bożego”, którego nie było w tekście Wielkiej Soboty).

Trzy kolejne stichery na „Panie, wołam” to mariologiczna adaptacja czterech sticher na stichownie wieczerni Wielkiego Piątku - śpiewanych tuż przed wyniesieniem całunu na środek cerkwi. Wszystkie są narracją rozpoczynającą się okolicznikiem ,kiedy”.

Pierwsza stichera - „Kiedy ze świata” - opiera się na wielkopiątkowej „Kiedy z drzewa”. Dzieli się na trzy części. Pierwsze dwie ilustrują wydarzenie rozpoczynając się odpowiednio okolicznikami „kiedy” (1) i „wtedy” (2) (nadając ton paralelnej budowie kolejnym sticherom z tego cyklu). Epilogiem jest doksologia wychwalająca Bożą kenozę (3).

Oryginalny hymn brzmi:

„1) Kiedy z drzewa, Arymatejczyk zdjął Ciebie, Życie wszystkich, Chryste,

2) wtedy owinąwszy Ciebie całunem i wonnościami namaściwszy, z miłością całował Twoje niezniszczalne ciało. Jednakże ogarnięty lękiem, tak wołał do Ciebie:

3) 'Chwała Twemu uniżeniu, Przyjacielu człowieka!’” (Wielki Tydzień, 2003, s. 94-95).

Sparafrazowany hymn Zaśnięcia:

„1) Kiedy ze świata zostałaś wzięta, Ty, która jesteś życiem, bo zrodziłaś Życie wszystkich, Syna Bożego w ciele, i wchodziłaś w Boże niebieskie bramy, Najczystsza,

2) wtedy spełniło się wygłoszone w Duchu Świętym proroctwo: 'Kim jest Ta, wstępująca z pustyni?' (Pnp 3,6), a wszystko z bojaźnią wołało:

3) 'Chwała Twemu wstępowaniu, o Najmiłościwsza!"” (Miesiaca sierpnia 15 dnia, s. 12).

Tekst nawiązuje do terminu „Życie wszystkich” użytego w odniesieniu do Chrystusa. Matka Boża jest Tą, która „Życie wszystkich” zrodziła. Hymn obwieszcza także wypełnienie proroctwa z Pieśni nad Pieśniami.

Ostatnią z pogrzebowych sticher wieczerni jest hymn „Ciebie, odziewającą się w światłość” będący parafrazą znamienitego doksastikonu piątego tonu na stichownie wielkopiątkowej wieczerni (następującego bezpośrednio po cytowanym wcześniej cyklu sticher).

Oryginalny hymn Wielkiego Piątku składa się z sześciu części, z czego cztery ostatnie są wypowiedzią w formie mowy niezależnej. To po kolei: peryfraza Chrystusa opisująca Jego wszechmoc (1), krótka narracja pogrzebu dokonanego przez Józefa i Nikodema oraz wprowadzenie do ich wypowiedzi (2), lamentacje (3), pytania retoryczne zawierające myśl o kontraście niemocy uczniów Chrystusa i wielkości Zbawiciela (4), uwielbienie Chrystusa (5), krótką doksologię, stanowiącą epilog hymnu (6):

„1) Ciebie, który odziewasz się w światłość jak w szatę,

2) Józef z Nikodemem zdjąwszy z krzyża, widząc martwego, obnażonego i niepogrzebanego, gorzkimi z serca zalewał się łzami i łkając mówił:

3) 'Biada mi, najsłodszy Jezu! Gdy przed chwilą słońce ujrzało Ciebie wiszącym na krzyżu, przyoblekło się w mrok, a ziemia zatrzęsła się z bojaźni, zasłona świątyni rozdarła się, a oto ja teraz widzę Ciebie, któryś za mnie podjął dobrowolną śmierć.

4) Jakże mogę pogrzebać Ciebie, Boże mój? Jakim całunem mam Ciebie owinąć? Jakimi rękoma można dotknąć niezniszczalne Twoje ciało? Jakież pieśni będę śpiewał przy Twoim pogrzebie, o Miłosierny?

5) Wywyższam Twoje cierpienia, wysławiam w pieśniach Twój pogrzeb i Twoje Zmartwychwstanie, wołając:

6) Panie, chwała Tobie"' (Wielki Tydzień, 2003, s. 9596).

Teomitoryczna wersja hymnu nie różni się w pierwszej i ostatniej części - $\mathrm{z}$ wyjątkiem zmiany adresata hymnu i konieczną w konsekwencji zmianę rodzaju gramatycznego na żeński. Brzmi ona następująco:

„1) Ciebie, która odziewasz się w światłość jak w szatę,

2) Rodzicielkę Syna Bożego, chór jego uczniów widząc martwą, położoną w mrocznym grobie, płakał gorąco i w płaczu wołał:

3) 'Biada mi, Najsłodsza Mariam, bo w małym miałem pociechę, widząc Ciebie myślałem, że widzę mego Nauczyciela, a teraz widzę Ciebie zmarłą zgodnie z prawem natury.

4) O jakże pogrzebię Ciebie, Dziewico, w jakie owinę całuny? Jakże dotknę się niezniszczalnego Twego ciała? Jakie godne śpiewy zaśpiewam Twemu odejściu? Jakże zniosę, Panie, tak bolesne dla mnie odejście? Jakże zniosę wielki ciężar sieroctwa?

5) Płaczę, błogosławiona Bogurodzico Mario, i bolejącym sercem układam pieśni, uwielbiam Ciebie, Pani, wyśpiewuję Twoje poczęcie, czczę Twoje Boże urodzenie, uwielbiam Twoje wstępowanie, Dziewico, Błogosławię Twoje zaśnięcie, najświętszy Twój pogrzeb i Twoje odejście, wołając:

6) Panie, chwała Tobie!" (Miesiaca sierpnia 15 dnia, s. 13).

Nadawcą wypowiedzi w częściach 3-6 jest chór apostołów

\section{Tropariony jutrzni}

Na jutrzni stanowiącej już stricte nabożeństwo pogrzebu Matki Bożej śpiewane są trzy tropariony, będące parafrazą troparionów wielkosobotnich. Według jednej z lokalnych praktyk to właśnie w tym momencie, podczas śpiewu tych hymnów na środek cerkwi wynoszony jest całun z ikoną Zaśnięcia. Chór śpiewa tropariony zwykle w charakterystycznej tzw. bułgarskiej melodii (botgarskij napiew), tak samo jak na nabożeństwie wielkotygodniowym.

Pierwszy troparion to „Dostojnych uczniów chór”. Parafrazuje on troparion wieczerni Wielkiego Piątku i jutrzni 
Wielkiej Soboty, będący krótkim opisem pogrzebu Chrystusa:

„Dostojny Józef z drzewa zdjął przeczyste Twoje ciało, całunem czystym owiną i wonnościami namaściwszy w nowym złożył grobie." (Wielki Tydzień, 2003, s. 105).

W hymnografii Pentekostarionu odnajdziemy także rozszerzoną wersję tego hymnu. W III Niedzielę po święcie Paschy (Niedzielę świętych niewiast niosących wonności), będącą paschalnym wspominaniem pogrzebu Chrystusa śpiewany jest tenże troparion rozbudowany o rezurekcyjny epilog:

„...Po trzech dniach zmartwychwstałeś, Panie, dając światu wielkie miłosierdzie." (Trzecia Niedziela, s. 4.)

Mariologiczna wersja troparionu pogrzebowego zbudowana jest podobnie $\mathrm{z}$ uwzględnieniem także drugiej rezurekcyjnej części. Brzmi ona następująco:

„1) Dostojnych uczniów chór Boży, teraz, o Czysta, niezniszczalne Twoje ciało oblawszy łzami jak wonnościami, w grobie złożył, czcigodnie grzebiąc,

2) ale po trzech dniach odeszłaś, Władczyni, dając światu Boże miłosierdzie" (Минея август, s. 55., thum. własne).

Drugi troparion - „Kiedy zstąpiłaś do śmierci” - parafrazuje kolejny troparion Wielkiej Soboty, będący także troparionem niedzielnym drugiego tonu. Oryginalny hymn to dwa zdania opowiadające o przebiegu zstąpienia Syna Bożego do otchłani w Błogosławioną Sobotę - 1a) kiedy ...., 1b) wtedy..., 2a) kiedy..., 2b) wtedy ... - zakończone doksologicznym epilogiem (3):

„1a) Kiedy zstąpiłeś do śmierci, Życie nieśmiertelne,

1b) wtedy otchłań zamarła od blasku Twego bóstwa,

2a) kiedy zaś i umarłych podźwignąłeś z głębin otchłani,

2b) wszystkie moce niebios wołały:

3) 'Dawco życia, Chryste Boże nasz, chwała Tobie!'” (Wielki Tydzień, 2003, s. 105-106).

Maryjna parafraza troparionu brzmi następująco:

„1a) Kiedy zstąpiłaś do śmierci, nieśmiertelna Matko Życia,

1b) wtedy otchłań zadziwiła się i ulękła,

2a) kiedy zaś ujrzano Cię, Mariam, odchodzącą z grobu na niebiosa,

2b) wszystkie moce niebios wołały:

3) 'Życiodajna Matko Życia naszego, chwała Tobie!'”

(Минея август, s. 55., tłum. własne).

Charakterystyczna jest praktyka przekształcania chrystologicznych metonimii „Życie” w maryjne metonimie „Matko Życia”.

Trzeci z cyklu troparionów („Pieśń, którą śpiewam”) wzorowany jest na hymnie mówiącym o objawieniu anioła (1) i radosnych słowach, które powiedział (2):

„1) Przed niewiastami niosącymi wonności przy grobie stanął anioł i zawołał:

2) 'Wonności dobre są dla zmarłych, Chrystus zaś okazał się niedostępny zepsuciu".

Podobnie jak w przypadku pierwszego troparionu w Pentekostarionie odnajdziemy jego rozszerzoną wersję.
W III Niedzielę po święcie Paschy do hymnu dodaje się epilog, będący przedłużeniem słów anioła - wezwaniem do głoszenia radości Zmartwychwstania:

„...Zaśpiewajcie przeto: Zmartwychwstał Pan, dając światu wielkie miłosierdzie" (Trzecia Niedziela, s. 4.).

Hymn z pogrzebu Bogurodzicy, chociaż powstał na kanwie tego wielkosobotniego, to jednak zbudowany jest nieco inaczej:

„1) Pieśń, którą śpiewam świętym uczniom niosących do Getsemani ciało Matki Bożej, jest dobra.

3) Przeto Matce Chrystusa, prawdziwemu Jedynemu Bożemu dziecięciu, zaśpiewajcie: 'Powstań, o Władczyni, dając wszystkim wielkie miłosierdzie" (Минея август, s. 55., thum. własne).

$\mathrm{Z}$ uwagi na pewną pozorną niekonsekwencję w adaptacji hymnu należy omówić dwie translatorskie uwagi. Hymn maryjny rozpoczyna się oryginalnie słowami „Священным учеником” (Świętym uczniom) analogicznie do początku chrystologicznego troparionu - „Мироносицам женам” (Niewiastom niosącym wonności). W thumaczeniu na język polski nie sposób było jednak nie dokonać inwersji składniowej i użycia przypadku innego niż celownik, stąd w polskojęzycznej wersji obu troparionów trudniej znaleźć analogię. Druga uwaga to przymiotnik „прилична”. W pierwszym troparionie anioł mówi, że wonności „мертвым суть прилична” (są odpowiednie, dobre dla zmarłych). W drugim zaś podmiot liryczny wspomina, że pieśń, którą śpiewa apostołom „прилична есть” (jest dobra, odpowiednia).

\section{Lamentacje}

Najobszerniejszą część obrzędu pogrzebu Bogurodzicy stanowią lamentacje - trzy stacje zbudowane strukturalnie i treściowo podobnie do tych wielkosobotnich. To krótkie wersety czytane zwykle przez duchownego przeplatane śpiewanymi przez chór wersetami psalmu 118., uznawanego $\mathrm{w}$ tradycji prawosławnej za psalm pogrzebowy. Oryginalne lamentacje Wielkiej Soboty są stosunkowo późnego pochodzenia - XVI-XVII w. (Zheltov).

Pierwsza stacja zawiera 72 wersety, druga -60 , trzecia - 44 (w sumie 176). Dodatkowo każdą stację kończą dwa dodatkowe wersety śpiewane na końcu do doksologii „Chwała”, „I teraz” - jeden dedykowany Trójcy Świętej, drugi - Bogurodzicy.

Tematy podejmowane $\mathrm{w}$ stacjach pogrzebowych są spójne z ogólnymi motywami hymnografii święta. Opracowano je na zasadzie podobieństwa, niekiedy parafrazy.

Pierwszy werset lamentacji chrystologicznych brzmi: „Chryste, Ty będąc Życiem złożony zostałeś w grobie, i ulękły się moce niebios, widząc Twoje upokorzenie" (Wielki Tydzień, 2003, s. 106). Tenże werset z pogrzebu Bogurodzicy - „Chryste, Ty będąc Życiem złożony zostałeś w grobie, i Matka Twoja w grobie jest składana, dziwny to widok dla aniołów i ludzi" (Miesiąca sierpnia 15 dnia, s. 14).

Lamentacje ilustrują odejście Zaśnięcie Bogurodzicy i towarzyszące mu wydarzenia. $\mathrm{W}$ ósmym wersecie 
słyszymy o objawieniu archanioła Gabriela: „Ponownie posłany został przez Boga Gabriel i Twoje odejście zwiastuje, o Przewyższająca Niebo, Nieskalana, Czysta" (Минея август, s. 56., tłum. własne). Dwunasty werset odnosi się do przejścia Bogurodzicy wraz z ciałem do niebios: „Dziewico, Twoje czcigodne ciało w grobie nie zaznało zniszczenia, ale z ciałem przeszłaś z ziemi na niebiosa" (Miesiaca sierpnia 15 dnia, s. 15).

O ile stacje pogrzebowe Wielkiej Soboty, a zwłaszcza kanon, wiele mówią o odnowieniu świata przez śmierć i Zmartwychwstanie Chrystusa, o tyle w Zaśnięciu hymnograf dopatruje się kolejnego uświęcenia ziemi. W wersecie 70. czytamy: „Ziemia będąc raz jeden przeklętą przez Boga, uświęcona została przez pogrzeb Boga naszego i teraz znowu przez Twój pogrzeb, Matko" (Miesiąca sierpnia 15 dnia, s. 18-19).

Werset 78. głosi: „Mądrość swój dom zabrała z ziemi do niebiańskiego domu i napełniła teraz Boską chwałą" (Miesiaca sierpnia 15 dnia, s. 19). To nawiązanie do kanonu Wielkiego Czwartku, w którym mowa jest o tym, iż Mądrość Boża, którą jest Syn Boży, zbudowała sobie dom w Bogurodzicy - „Przyczyna wszystkiego i dawczyni życia, niezmierzona Mądrość Boża, zbudowała sobie dom z czystej Matki nieznającej męża. W dom ciała bowiem przyodział się i chwalebnie wysławił się Chrystus" (Wielki Tydzień, 2003, s. 40). Słowa odnoszą się do misterium Wcielenia Chrystusa. Po Zaśnięciu Chrystus zabiera ciało i duszę Swojej Matki, co ma swoje odzwierciedlenie zarówno w hymnografii, jak i ikonografii święta - zostało to już omówione w poprzedniej części artykułu.

Wiele miejsca $\mathrm{w}$ lamentacjach poświęca się orędownictwu Bogurodzicy. Ma to za zadanie pokrzepienie wiernych opłakujących ziemskie odejście Matki Bożej. Piąty werset głosi - „Odeszłaś z ziemi i nigdy z ziemią nie rozłączyłaś się, Najświętsza Bogurodzico, wybawiając cały świat z nieszczęść" (Miesiąca sierpnia 15 dnia, s. 14). Retoryczne pytanie wołającego podmiotu lirycznego pada w wersecie 62.: „Gdzie odchodzisz, Dziewico? Gdzie przechodzisz teraz? Wzleciałaś ponad niebiosa, pozostawiwszy na ziemi pisklęta?" (Miesiaca sierpnia 15 dnia, s. 18). Werset 128. to z kolei modlitewne wezwanie dotyczące spokoju w Kościele: „Wycisz zgorszenia w Kościele i umocnij go, jako Dobra" (Miesiaca sierpnia 15 dnia, s. 23).

Warto wspomnieć o nawiązaniu do wesela w Kanie Galilejskiej. W kontakionie Wielkiego Piątku autorstwa św. Romana Melodosa Matka Boża opłakująca idącego na śmierć Chrystusa pyta retorycznie: „Gdzie podążasz, Dziecię? (...) Czyżby nowe wesele odbywało się w Kanie i tam teraz dążysz, aby wodę przemienić w wino? Czy mam iść z Tobą, Dziecię, czy też raczej poczekam na Ciebie?" (Wielki Tydzień, 2003, s. 78). Na kanwie tego hymnu podmiot liryczny zwraca się do Matki Bożej słowami 148. wersetu lamentacji: „Czyżbyś znowu do Kany na wesele została teraz zaproszona z Apostołami?” (Miesiaca sierpnia 15 dnia, s. 24). Teraz zatem to Bogurodzica jest adresatką podobnego pytania, które w Wielki Piątek zadała Swojemu Synowi.

\section{Eulogitaria maryjne}

Na jutrzni Wielkiej Soboty bezpośrednio po trzech stacjach śpiewane są „,tropariony po nieskalanych” zwane także eulogitariami - od refrenu „Błogosławiony jesteś Panie,

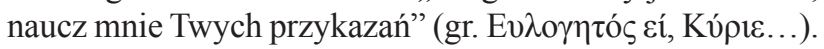
O ile stacje miały charakter funeralny - nawiązywały w swojej treści do pogrzebu Chrystusa, coraz wyraźniej jednak zwiastując jego triumfalne zstąpienie do otchłani i Zmartwychwstanie - o tyle eulogitaria mają charakter wyraźnie rezurekcyjny. $\mathrm{W}$ trakcie roku liturgicznego zarezerwowane są wyłącznie dla niedzielnych jutrzni (a także stanowiących wyjątki - Soboty Łazarza i Wielkiej Soboty). Podobnie jest na jutrzni pogrzebu Bogurodzicy. Po lamentacjach chór śpiewa radosne eulogitaria mówiące o zmartwychwstaniu Najświętszej Dziewicy. Podobnie jak w Wielką Sobotę tropariony te śpiewane są według tonu piątego (paschalnego). Każdy z troparionów poprzedza krótki refren - „Błogosławiona Władczyni, oświeć mnie światłością Twego Syna” (Miesiaca sierpnia 15 dnia, s. 26).

Pierwszy troparion eulogitariów w chrystologicznym oryginale brzmi:

„1) Chóry aniołów zadziwiły się, widząc Ciebie, policzonego ze zmarłymi,

2) zniszczyłeś, Zbawco, moc śmierci, i podniosłeś ze sobą Adama, i wszystkich uwalniasz z otchłani”" (Wielki Tydzień, 2003, s. 128).

Mariologiczna wersja hymnu to:

„1) Chóry aniołów zadziwiły się, widząc Ciebie, policzoną ze zmarlymi,

2) duszę oddającą w ręce Boga i z Bogiem wstępującą, Najczystsza, z chwałą Bożą do Niebios" (Минея авгусm, s. 75-76., thum. własne)

Utwór porusza dość częsty w hymnografii motyw aniołów, które - widząc dokonujące się wielkie misterium przewyższające ich rozum - zadziwiają się. Temat ten pojawia się również w dziewiątej pieśni kanonu wielu świąt - w specjalnych refrenach.

Kolejny troparion jest wzorowany na tekście o trzyczęściowej budowie: pytaniu do uczennic (1), wprowadzeniem postaci anioła (2) i jego cytatem (3):

„1) Dlaczego, uczennice, mieszacie mirrę ze łzami?

2) W grobie anioł błyszczący mówi miroforom:

3) 'Spójrzcie na grób i zrozumcie, że Zbawiciel powstał z grobu"' (Минея август, s. 76., thum. własne)

Maryjny hymn ma tę samą budowę. W pierwszej części podmiot liryczny zwraca się z pytaniem do apostołów, następnie cytowany jest apostoł Tomasz (Bliźniak, Didymos), który przekonuje pozostałych o zmartwychwstaniu Bogurodzicy.

„1) Dlaczego, Boży głosiciele, mieszacie radość ze łzami?

2) Przyszedł Bliźniak pouczony z wysoka i rzecze apostołom:

3) 'Spójrzcie na pas i zrozumcie, że Dziewica powstała z grobu" (Miesiaca sierpnia 15 dnia, s. 26).

Postać Tomasza będzie przewodnim tematem także kolejnych troparionów. 
Pierwowzór trzeciego z eulogitariów jest także trzyczęściowy - pierwsze zdanie (1), zwrot akcji (2) i ponownie cytat (3):

„1) Wcześnie rano mirofory biegły do twego grobu ze łkaniem,

2) Ale stanął przed nimi anioł i powiedział:

3) 'Skończył się czas płaczu, nie płaczcie, głoście apostołom Zmartwychwstanie"” (Wielki Tydzień, 2003, s. 128).

Podobnie zbudowana jest maryjna parafraza:

„1) Władczyni, uczeń wątpiący w zmartwychwstanie Twego Syna

2) teraz przekonuje innych o Twoim powstaniu, mówiąc:

3) 'Ustał czas płaczu, nie szlochajcie już, ale głoście zmartwychwstanie Dziewicy" (Miesiaca sierpnia 15 dnia, s. 26)

Ponownie bohaterem hymnu staje się apostoł Tomasz. W utworze zostały skontrastowane dwa wydarzenia - udział apostoła w Zmartwychwstaniu Chrystusa i znaczenie przy zaśnięciu Bogurodzicy. Za pierwszym razem był on tym, który powątpiewał. Po pogrzebie Matki Bożej stał się zaś tym, dzięki któremu wszyscy pozostali zdali sobie sprawę, że ciała Najświętszej Dziewicy nie ma już w grobie.

Czwarty troparion ma budowę podobną do drugiego - podanie okoliczności (1), wprowadzeniem postaci (2) i cytat (3). W chrystologicznej wersji brzmi on następująco:

„1) Niewiasty mirofory z mirrą przyszedłszy do Twego grobu, Zbawco, płakały,

2) lecz anioł rzekł im:

3) 'Dlaczego do zmarłych zaliczacie Żywego? Jako Bóg zmartwychwstał z grobu" (Wielki Tydzień, 2003, s. 128).

Maryjna wersja zbudowana jest podobnie. Zamiast anioła ponownie pojawia się apostoł Tomasz:

„1) Dziewico, Chrystusowym uczniom, zgromadzonym przy Twoim grobie i płaczącym,

2) zjawił się Tomasz i powiedział:

3) 'Dlaczego myślicie, że Żywa jest pośród umarłych?
Zmartwychwstała jako Rodzicielka Życia" (Miesiaca sierpnia 15 dnia, s. 26)

Przedostatni troparion śpiewany po doksologii „Chwała...” jest wychwaleniem Trójcy Świętej. W obu wersjach eulogitariów jest on identyczny.

Ostatni troparion to teotokion - hymn adresowany do Matki Bożej. W przypadku eulogitariów ku czci Zmartwychwstania Chrystusa jest to jedyny troparion ku czci Bogurodzicy. Można go podzielić na trzy części: wprowadzenie - zrodzenie Chrystusa (1), skutki (2), wątek chrystologiczny (3):

„1) Dawcę życia zrodziwszy,

2) Dziewico, od grzechu uwolniłaś Adama, radość zaś Ewie dałaś zamiast bólu,

3) odpadłych zaś od życia skierował ku życiu wcielony w Ciebie Bóg i człowiek" (Akolouthia, tłum. własne)

Eulogitaria ku czci Bogurodzicy mają inną wersję tego hymnu, powielając budowę i cytując pierwszą część:

„1) Dawcę życia zrodziwszy,

2) przeszłaś do życia wiecznego, Dziewico, radość zamiast smutku dałaś uczniom,

3) z grobu po trzech dniach powstawszy, tak jak Pan" (Минея август, s. 76., thum. własne)

\section{Zakończenie}

Hymnografia Zaśnięcia Bogurodzicy wielokrotnie i w różny sposób odwołuje się do hymnografii Wielkiego Tygodnia, zwłaszcza Wielkiej Soboty. Podobieństwa można odnaleźć w aspekcie konstrukcji utworów, a także wzajemnej zależności - tematowej, stylistycznej i frazeologicznej. Taka intertekstualność, choć dostrzegalna szczególnie w przypadku materiału liturgicznego święta Zaśnięcia Bogurodzicy, nie jest cechą jedynie tego święta. Wzajemne przenikanie się tekstologiczne hymnów pojawia się w kontekście wielu świąt i wielu świętych. Świadczy to o bogactwie hymnografii i kunszcie jej twórców, których zadaniem jest nie tylko kompozycja tekstów i dobranie bądź stworzenie warstwy muzycznej, ale też dogłębna refleksja nad korespondencją nowych utworów z już istniejącymi.

\section{Bibliografia}

Akolouthia tou orthrou psalletai th Agia kai Megalh Paraskevh esperas. [online] http://www.christopherklitou.com/holy_ and_great_saturday_mattins_greek.htm [12.06.2020]

Charkiewicz, J. (2013). Wielkie święta prawosławne. Zarys historii i ikonografii. Warszawa.

Karabinov, I. (1910). Postnaja Triod'. Istoricheskij obzor. Sankt -Peterburg. [Карабинов, И. (1910). Постная Триодь. Исторический обзор. Санкт-Петербург.].

Miesiąca sierpnia 15 dnia. Zaśnięcie Najświętszej Władczyni Naszej Bogurodzicy i Zawsze Dziewicy Marii, (H. Paprocki, thum), [online] http://www.liturgia.cerkiew.pl/pages/File/ docs/festum-38-zasniecie.pdf. [15.06.2020].
Mineja avgust. 2. Chast'vtoraja. (1989). Moskva. [Минея август. 2. Часть вторая. (1989). Москва.].

Pljukhanova, M. (2016). Kipenije sveta. Russkie Odigitrii v liturgicheskoj poezii $i v$ istorii. Sankt-Peterburg. [Плюханова, М. (2016). Кипение света. Русские Одигитрии в литургической поезии и в истории. Санкт-Петербург.].

Quenot, M. (2014). Zmartwychwstanie i ikona. (H. Paprocki, Tłum.). Białystok.

Skaballanovich, M.N. (2004). Uspenie Presvjatoj Bogorodicy. Kiev. [Скабалланович, М.Н. (2004). Успение Пресвятой Богородицы. Киев.]. 
Th IE' tou autou mhnos. Mnhmh ths Koimhseos ths Yperagias Despoinhs hmon Theotokou kai aeiparthenou Marias. [online] http://www.christopherklitou.com/menaia_15_august_ greek.htm [3.07.2020].

Trzecia Niedziela po święcie Paschy, świętych niewiast niosacych mirrę i Józefa Sprawiedliwego. (H. Paprocki, Tłum.). [on- line] http://www.liturgia.cerkiew.pl/pages/File/docs/riodion04-tydzien-iii.pdf. [20.06.2020].

Wielki Tydzień i święto Paschy w Kościele prawosławnym (2003). (H. Paprocki, Tłum.). Kraków.

Zheltov, M. Obshchaja kompozicija sluzhb Strastnoj Sedmicy [Желтов, М. Обшчая композиция служб Страстной Седмицы]. [online] bogoslov.ru/article/397608. [2.07.2020]

Rozmiar artykułu: 1,3 arkusza wydawniczego 